\title{
Phylogeny of nodulation and nitrogen-fixation genes in Bradyrhizobium: supporting evidence for the theory of monophyletic origin, and spread and maintenance by both horizontal and vertical transfer
}

Correspondence

Mariangela Hungria mariangela.hungria@embrapa.br or hungria@pq.cnpq.br

\section{INTRODUCTION}

Some prokaryotes have a remarkable capacity to fix atmospheric nitrogen, thus providing it in a utilizable form

Abbreviation: LCOs, lipo-chitin oligosaccharides.

The GenBank/EMBL/DDBJ accession numbers for the sequences reported in this paper are given in Figs 1-4.

Two supplementary figures and a table are available with the online version of this paper.

\author{
Pâmela Menna ${ }^{1,2}$ and Mariangela Hungria ${ }^{1,2}$ \\ ${ }^{1}$ Embrapa Soja, Cx Postal 231, 86001-970 Londrina, Paraná, Brazil \\ ${ }^{2}$ Conselho Nacional de Desenvolvimento Científico e Tecnológico (CNPq-MCT), Brasilia, Federal \\ District, Brazil
}

\begin{abstract}
Bacteria belonging to the genus Bradyrhizobium are capable of establishing symbiotic relationships with a broad range of plants belonging to the three subfamilies of the family Leguminosae (=Fabaceae), with the formation of specialized structures on the roots called nodules, where fixation of atmospheric nitrogen takes place. Symbiosis is under the control of finely tuned expression of common and host-specific nodulation genes and also of genes related to the assembly and activity of the nitrogenase, which, in Bradyrhizobium strains investigated so far, are clustered in a symbiotic island. Information about the diversity of these genes is essential to improve our current poor understanding of their origin, spread and maintenance and, in this study, we provide information on 40 Bradyrhizobium strains, mostly of tropical origin. For the nodulation trait, common (nodA), Bradyrhizobium-specific (nodY/K) and host-specific (nodZ) nodulation genes were studied, whereas for fixation ability, the diversity of nifH was investigated. In general, clustering of strains in all nod and nifH trees was similar and the Bradyrhizobium group could be clearly separated from other rhizobial genera. However, the congruence of nod and nif genes with ribosomal and housekeeping genes was low. nod $A$ and nod $Y / K$ were not detected in three strains by amplification or hybridization with probes using Bradyrhizobium japonicum and Bradyrhizobium elkanii type strains, indicating the high diversity of these genes or that strains other than photosynthetic Bradyrhizobium must have alternative mechanisms to initiate the process of nodulation. For a large group of strains, the high diversity of nod genes (with an emphasis on nodZ), the low relationship between nod genes and the host legume, and some evidence of horizontal gene transfer might indicate strategies to increase host range. On the other hand, in a group of five symbionts of Acacia mearnsii, the high congruence between nod and ribosomal/housekeeping genes, in addition to shorter nodY/K sequences and the absence of nodZ, highlights a co-evolution process. Additionally, in a group of $B$. japonicum strains that were symbionts of soybean, vertical transfer seemed to represent the main genetic event. In conclusion, clustering of $\operatorname{nodA}$ and $n i f H$ gives additional support to the theory of monophyletic origin of the symbiotic genes in Bradyrhizobium and, in addition to the analysis of nod $Y / K$ and nodZ, indicates spread and maintenance of nod and nif genes through both vertical and horizontal transmission, apparently with the dominance of one or other of these events in some groups of strains.
\end{abstract}

(ammonia) to plants. The capacity to fix nitrogen is determined by a highly conserved enzyme complex called nitrogenase, which is inactivated in the presence of oxygen (Zehr et al., 1993; Angus \& Hirsch, 2010). Nitrogenase probably arose in the Archean age and, throughout evolution, has been maintained in several genera that are collectively known as diazotrophic micro-organisms (Dixon \& Kahn, 2004). Diazotrophs are found in a variety of phylogenetic groups such as green sulphur bacteria, firmibacteria, actinomycetes, cyanobacteria and all subdivisions of 
the Proteobacteria, and, in Archaea, the nitrogen fixation trait predominates in the methanogenic group (Dixon \& Kahn, 2004; Lloret \& Martínez-Romero, 2005; Angus \& Hirsch, 2010).

The symbiotic association between diazotrophic bacteria commonly known as rhizobia with plants probably arose later, with the emergence of the first terrestrial plants, and was established mainly with members of the family Leguminosae (=Fabaceae), which arose 60-65 million years ago. Symbiotic nitrogen fixation is a highly complex process and, in bacteria, involves the expression of several genes, including those related to the assembly and activity of the nitrogenase (nif and fix) and others (nod, nol and noe) related to the formation of highly specialized structures, the nodules, where this process takes place. These genes are clustered in complex operons located either in plasmids (e.g. in Rhizobium species, Sinorhizobium species, Mesorhizobium amorphae, Mesorhizobium huakuii) or in symbiotic islands flanked by insertion sequences (e.g. in Mesorhizobium loti and Bradyrhizobium japonicum) (Freiberg et al., 1997; Göttfert et al., 2001; Kaneko et al., 2002; Lloret \& Martínez-Romero, 2005).

Nodulation genes are responsible for the production of chitooligosaccharides, also called Nod factors. Usually Nod factors are responsible for the specificity between plants and bacteria and consist of chitin oligomers mono $\mathrm{N}$ acylated at the non-reducing end with distinct substituents at both ends of the molecule; in the majority of rhizobia studied so far, synthesis of these molecules is controlled by the nod $A B C$ genes. In addition, distinct rhizobia carry different combinations of nodulation genes that were probably recruited from paralogues during the course of evolution and are named 'host-specific nodulation genes' (hsn) (Lerouge et al., 1990; Broughton et al., 2000; Lloret \& Martínez-Romero, 2005). It is generally believed that natural events of lateral gene transfer and duplication of nodulation genes have contributed to the evolution and spread of symbiotic ability throughout several genera of bacteria (Barcellos et al., 2007; Zhao et al., 2008).

The genus Bradyrhizobium encompasses diazotrophic bacteria that can live in symbiotic and endophytic association with legumes and non-legumes, and are characterized by physiological and symbiotic versatility and broad geographic distribution. Bradyrhizobium is the most abundant rhizobial group identified in root nodules of legumes growing in tropical and subtropical areas and the genus is also wellknown for its broad host range, which is an adaptation allowing persistence in tropical areas that are known for their high legume diversity. In previous studies by our group, symbionts from plants belonging to the three subfamilies of the family Leguminosae have demonstrated great genetic diversity in their 16S rRNA and other housekeeping genes (Menna et al., 2006, 2009a, b). It has also been shown that analysis of nitrogen fixation and nodulation genes may provide valuable information about the evolution of Bradyrhizobium (Stępkowski et al., 2005;
Stępkowski et al., 2007; Steenkamp et al., 2008). For example, studies of nodA, nodZ, nolL and noeI genes in Bradyrhizobium have shown a monophyletic origin and comparison with housekeeping genes has indicated that the spread and maintenance of the nod genes seem to have occurred mainly through vertical transmission, although lateral gene transfer might also have played a significant role (Moulin et al., 2004; Stępkowski et al., 2005, 2007; Steenkamp et al., 2008).

In this study, the genetic diversity of nodulation and nitrogen-fixation genes was analysed in 40 Bradyrhizobium strains, symbionts isolated from a variety of legume species, mostly of tropical origin. For the nodulation trait, common and host-specific genes $(\operatorname{nod} Y / K$, nodA, nodZ) were examined whereas, for nitrogen-fixation ability, the diversity of nifH was investigated. In addition to showing high diversity of nod and nif genes, our results reveal a complex evolutionary pattern for tropical Bradyrhizobium species.

\section{METHODS}

Strains. Forty Bradyrhizobium SEMIA strains from the Brazilian Rhizobium Culture Collection SEMIA of the FEPAGRO-MIRCEN [Fundação Estadual de Pesquisa Agropecuária (Rio Grande do Sul, Brazil) - Microbiological Resources Center] (IBP World Catalogue of Rhizobium Collections no. 443 in the World Federation of Culture Collections) were used in this study (Table 1). The strains were isolated from members of the three subfamilies and ten tribes of the family Leguminosae (=Fabaceae) (Table 1). The strains are deposited in the Diazotrophic and Plant Growth Promoting Bacteria Culture Collection of Embrapa Soja (http://www.bmrc.lncc.br). Preparation of stock cultures, strain growth conditions and maintenance were as described by Menna et al. (2006).

DNA extraction, amplification and sequencing of nod and nif genes. Total genomic DNA of each strain was extracted from bacterial batch cultures grown in YM broth until late exponential phase $\left(10^{9}\right.$ cells $\left.\mathrm{ml}^{-1}\right)$ and extraction of DNA was performed as described previously (Menna et al., 2006). DNA from each strain was amplified by using specific primers for the regions coding for nodY/K, $\operatorname{nodA}, \operatorname{nodZ}$ and nifH genes (Table 2). For each PCR, 40 ng DNA was used; primers, amplification conditions and references are listed in Table 2. PCR products were purified using the QIAquick PCR Purification kit (Qiagen) and sequencing was performed as described by Menna et al. (2006). Some PCR products (nifH of SEMIA 6156, SEMIA 6434 and SEMIA 6014) had to be cloned with the pGEM Easy Vector Systems (Promega), according to the manufacturer's instructions, before sequencing.

Cluster analyses. After sequencing, the nucleotide sequences generated were analysed with the programs Phred, Phrap and Consed, as described previously (Menna et al., 2009a). The sequences obtained were confirmed in the $5^{\prime}$ and $3^{\prime}$ directions and submitted to GenBank; accession numbers are listed in Figs 1-4. Sequences were analysed using the software MEGA version 4.0 with default parameters, the K2P distance model (Kimura, 1980) and the neighbourjoining algorithm (Saitou \& Nei, 1987). Statistical support for the tree nodes was evaluated by bootstrap analyses (Felsenstein, 1985) with 1000 samplings (Hedges, 1992). Accession numbers of reference/ type strains used for alignment and comparison are also listed in Figs 1-4. 
Table 1. Bradyrhizobium strains used in this study

\begin{tabular}{|c|c|c|c|c|c|c|}
\hline Strain & $\begin{array}{l}\text { Classification- } \\
\text { based MLSA }\end{array}$ & Biovar & Other designations & Host plant $\dagger$ & Common name & Geographic origin \\
\hline SEMIA 511 & B. japonicum & glycinearum & UW 511, USDA 500 & Glycine $\max \left(\mathrm{L}\right.$.) Merr. ${ }^{3,7}$ & Soybean & USA \\
\hline SEMIA 512 & B. japonicum & glycinearum & 3I1b73 (USDA-Dr Erdman) & Glycine max (L.) Merr. ${ }^{3,7}$ & Soybean & USA \\
\hline SEMIA 560 & Bradyrhizobium sp. & glycinearum & No synonyms & Glycine $\max \left(\right.$ L.) Merr. ${ }^{3,7}$ & Soybean & Brazil \\
\hline SEMIA 587 & B. elkanii & & BR 96 & Glycine $\max (\mathrm{L}$.$) Merr. { }^{3,7}$ & Soybean & Brazil \\
\hline SEMIA 656 & Bradyrhizobium sp. & & Original SEMIA & $\begin{array}{l}\text { Neonotonia wightii (Wight \& Arn.) J. A. } \\
\text { Lackey }^{3,7}\end{array}$ & Perennial soybean & Brazil \\
\hline SEMIA 695 & B. elkanii & & E 85, QA 922, SU 422, NA 630 & $\begin{array}{l}\text { Neonotonia wightii (Wight \& Arn.) J. A. } \\
\text { Lackey }^{3,7}\end{array}$ & Perennial soybean & Australia \\
\hline SEMIA 928 & B. canariense & genistearum & $\mathrm{W}-72$ & Lupinus sp. ${ }^{3,13}$ & Lupin & Not known \\
\hline SEMIA 5011 & B. elkanii & & Original SEMIA & Glycine $\max \left(\right.$ L.) Merr. ${ }^{3,7}$ & Soybean & Brazil \\
\hline SEMIA 5019 & B. elkanii & & $29 \mathrm{~W}, \mathrm{BR} 29$ & Glycine $\max \left(\right.$ L.) Merr. ${ }^{3,7}$ & Soybean & Brazil \\
\hline SEMIA 5025 & B. liaoningense & glycinearum & TAL 411 , Tha3 & Glycine $\max$ (L.) Merr. ${ }^{3,7}$ & Soybean & Thailand \\
\hline SEMIA 5026 & B. elkanii & & TAL 415 , THA 9 & Glycine $\max \left(\right.$ L.) Merr. ${ }^{3,7}$ & Soybean & Thailand \\
\hline SEMIA 5027 & B. elkanii & & TAL $183,61 \mathrm{a} 76$ & Glycine $\max$ (L.) Merr. ${ }^{3,7}$ & Soybean & USA \\
\hline SEMIA 5045 & B. japonicum & glycinearum & Nit $123 \mathrm{P} 35$ & Glycine max (L.) Merr. ${ }^{3,7}$ & Soybean & Not known \\
\hline SEMIA 5062 & B. liaoningense & & SVJ-04 & Glycine $\max (\mathrm{L}$.$) Merr. { }^{3,7}$ & Soybean & Brazil \\
\hline SEMIA 5079 & B. japonicum & glycinearum & CPAC 15, DF 24 & Glycine $\max (\mathrm{L}$.$) Merr. { }^{3,7}$ & Soybean & Brazil \\
\hline SEMIA 5080 & B. japonicum & glycinearum & CPAC 7 & Glycine $\max \left(\right.$ L.) Merr. ${ }^{3,7}$ & Soybean & Brazil \\
\hline SEMIA 6014 & Bradyrhizobium sp. & & CIAT 1316, USM 128, TAL 405 & Stylosanthes guianensis (Aubl.) Sw., & Stylosanthes & Peru \\
\hline SEMIA 6028 & Bradyrhizobium sp. & & TAL 569, SPRL 472, MAR 472 & Desmodium uncinatum (Jacq.) DC. 3,11 & Silverleaf Desmodium & Zimbabwe \\
\hline SEMIA 6053 & Bradyrhizobium sp. & & TAL 827, UMKI 28 & Clitoria ternatea L.,7 & Blue-pea & Malaysia \\
\hline SEMIA 6059 & B. japonicum & & USDA 3309 & Psophocarpus tetragonolobus (L.) DC. ${ }^{3,7}$ & Winged bean & USA \\
\hline SEMIA 6069 & Bradyrhizobium sp. & & DF 10 & Leucaena leucocephala (Lam.) ${ }^{1,12}$ & Jumbie bean & Brazil \\
\hline SEMIA 6077 & B. yuanmingense & & CB 82 & Stylosanthes sp. ${ }^{3,5}$ & Stylosanthes & Australia \\
\hline SEMIA 6093 & Bradyrhizobium sp. & & USDA 3331 & Aeschynomene americana L. ${ }^{3,5}$ & Shyleaf & USA \\
\hline SEMIA 6099 & Bradyrhizobium sp. & & BR 5004, LMG 9989 & Dimorphandra exaltata Schott ${ }^{2,10}$ & Dimorphandra & Brazil \\
\hline SEMIA 6101 & Bradyrhizobium sp. & & BR 8404 & Dalbergia nigra (Vell.) Benth.,9 & Brazilian rosewood & Brazil \\
\hline SEMIA 6146 & Bradyrhizobium sp. & & BR 1808 & Centrosema sp. ${ }^{3,7}$ & Centrosema & Brazil \\
\hline SEMIA 6148 & Bradyrhizobium sp. & & SMS 303 & $\begin{array}{l}\text { Neonotonia wightii (Wight \& Arn.) J. A. } \\
\text { Lackey }\end{array}$ & Perennial soybean & Brazil \\
\hline SEMIA 6152 & Bradyrhizobium sp. & & BR-1602 & Calopogonium sp.,7 & Calopogonium & Brazil \\
\hline SEMIA 6156 & Bradyrhizobium sp. & & CPAC IJ & Crotalaria spectabilis Roth $^{3,8}$ & Rattlebox & Brazil \\
\hline SEMIA 6160 & Bradyrhizobium sp. & & BR 5610 & Albizia lebbeck (L.) Benth. ${ }^{1,6}$ & Rain tree & Brazil \\
\hline SEMIA 6163 & Bradyrhizobium sp. & & BR 3607 & Acacia mearnsii De Wild. ${ }^{1,4}$ & Black Wattle & Brazil \\
\hline SEMIA 6164 & Bradyrhizobium sp. & & BR 3608, LMG 9960 & Acacia mearnsii De Wild. ${ }^{1,4}$ & Black Wattle & Brazil \\
\hline SEMIA 6179 & Bradyrhizobium sp. & & Original SEMIA & Acacia mearnsii De Wild. ${ }^{1,4}$ & Black Wattle & Brazil \\
\hline SEMIA 6186 & Bradyrhizobium sp. & & Original SEMIA & Acacia mearnsii De Wild. ${ }^{1,4}$ & Black Wattle & Brazil \\
\hline SEMIA 6187 & Bradyrhizobium sp. & & Original SEMIA & Acacia mearnsii De Wild. ${ }^{1,4}$ & Black Wattle & Brazil \\
\hline SEMIA 6192 & Bradyrhizobium sp. & & Original SEMIA & Tipuana tipu $u^{3,9}$ & Tipu & Brazil \\
\hline SEMIA 6319 & B. yuanmingense & & NC 92 & Arachis sp. ${ }^{3,5}$ & Arachis & Bolivia \\
\hline
\end{tabular}


Southern hybridization assays. Each DNA sample (500 ng) was digested overnight with $2 \mu \mathrm{l} \mathrm{EcoRI}$ restriction endonuclease (10 U $\mu^{-1}$; Invitrogen), separated in $1 \%$ agarose gel and then transferred to a Hybond-N + membrane (Amersham Biosciences) by the Southern blot standard procedure (Sambrook \& Russell, 2001). Labelling of probes and hybridization procedures were performed using the AlkPhos Direct labelling reagents (Amersham Biosciences), according to the manufacturer's instructions. The nodZ, nodA and nodY/K partial genes from Bradyrhizobium japonicum strain USDA $6^{\mathrm{T}}$ and Bradyrhizobium elkanii strain USDA $76^{\mathrm{T}}$, amplified as described in Table 2, were used as probes. Escherichia coli TOP10 was used as control for the hybridization assay. After hybridization, detection was carried out using CDP-Star reagent in a Hypercassette (both Amersham Biosciences), according to the manufacturer's instructions.

\section{RESULTS}

\section{Ribosomal and housekeeping genes}

To allow a comparison with nodulation and nitrogen fixation genes, phylogenetic trees built with 16S rRNA genes (Supplementary Fig. S1, available in IJSEM Online) and with the concatenated housekeeping genes dnaK, glnII and recA (Supplementary Fig. S2, available in IJSEM Online) were included. The trees were rebuilt using the 40 strains from this study and sequences previously obtained by Menna et al. (2009a). In the $16 \mathrm{~S}$ rRNA gene phylogenetic tree, strains were split into two well supported clusters (I and II), with the majority of the strains (23 out of 40 ) being related to B. japonicum, Bradyrhizobium yuanmingense, Bradyrhizobium liaoningense, Bradyrhizobium betae and Bradyrhizobium canariense type/reference strains. Strains in cluster II showed high similarity to the type strains of Bradyrhizobium jicamae, Bradyrhizobium pachyrhizi and $B$. elkanii (Supplementary Fig. S1). In both clusters I and II of the 16S rRNA gene tree, subdivision into subclusters was unclear; therefore, phylogeny of housekeeping genes was also performed. The tree built with the three housekeeping genes also split the strains into two main clusters (I and II); however, subclusters were more clearly observed (Table 3; Supplementary Fig. S2).

\section{Nodulation genes}

No amplification products were formed with the TSnodD1-1a/TSnodB1 primers for three of the 40 strains: SEMIA 6014 (from Stylosanthes guianensis), SEMIA 6192 (from Tipuana tipu) and SEMIA 6434 (from Inga sp.). For the remaining strains, fragments of about $2 \mathrm{~kb}$ containing the whole nodD-nodA intergenic region (i.e. nod box and $n o d Y / K)$, the nodA gene and 230-530 bp of the nodB gene were obtained. Shorter fragments of about $1800 \mathrm{bp}$ were obtained for strains SEMIA 6186, 6164, 6163, 6187 and 6179, all symbionts of Acacia mearnsii. The $2 \mathrm{~kb}$ fragments obtained from PCR amplification were submitted to a new PCR cycle with the primer set TSnodD1-1a/TSnodA2, resulting in fragments of about $1200 \mathrm{bp}$, except again for SEMIA strains 6186, 6164, 6163, 6187 and 6179, which resulted in fragments of about 800 bp but, in both cases, 
Table 2. Primers and DNA amplification conditions used in this study

\begin{tabular}{|c|c|c|c|c|c|}
\hline Primer & Sequence $\left(5^{\prime} \rightarrow 3^{\prime}\right)^{\star}$ & $\begin{array}{l}\text { Target gene } \\
\text { (position) } \dagger\end{array}$ & $\begin{array}{c}\text { Amplified } \\
\text { genes in PCR }\end{array}$ & PCR cycling & Reference \\
\hline $\begin{array}{l}\text { TSnodD1-1a } \\
\text { TSnodB1 }\end{array}$ & $\begin{array}{l}\text { CAGATCNAGDCCBTTGAARCGCA } \\
\text { AGGATAYCCGTCG TGCAGGAGCA }\end{array}$ & $\begin{array}{l}\operatorname{nodD1}(24-2) \\
\operatorname{nodB}(534-512)\end{array}$ & $\begin{array}{l}\operatorname{nod} \text { box } \$ \\
\operatorname{nod} Y / K \$ \\
\operatorname{nod} A \$\end{array}$ & $\begin{array}{l}2 \min 94{ }^{\circ} \mathrm{C}, 20 \times \\
\left(1 \min 94{ }^{\circ} \mathrm{C}, 2 \min \right. \\
\text { using temperature } \\
\text { rescinding from } 60 \text { to } \\
\left.50{ }^{\circ} \mathrm{C}, 2 \min 72^{\circ} \mathrm{C}\right), \\
7 \min 72^{\circ} \mathrm{C}\end{array}$ & $\begin{array}{l}\text { Moulin et al. } \\
(2004)\end{array}$ \\
\hline $\begin{array}{l}\text { TSnodD1-1a } \neq \\
\text { TSnodA2 } \neq\end{array}$ & $\begin{array}{l}\text { CAGATCNAGDCCBTTGAARCGCA } \\
\text { GCTGATTCCAAGBCCYTCVAGATC }\end{array}$ & $\begin{array}{l}\operatorname{nodD1}(24-2) \\
\operatorname{nodA}(348-325)\end{array}$ & $\begin{array}{l}\operatorname{nod} \text { box } \$ \\
\operatorname{nod} Y / K \S \\
\operatorname{nod} A l l\end{array}$ & $\begin{array}{l}1 \min 95{ }^{\circ} \mathrm{C}, \\
29 \times\left(45 \mathrm{~s} 95{ }^{\circ} \mathrm{C}, 30 \mathrm{~s}\right. \\
\left.58{ }^{\circ} \mathrm{C}, 1.5 \min 72{ }^{\circ} \mathrm{C}\right), \\
5 \min 72{ }^{\circ} \mathrm{C}\end{array}$ & $\begin{array}{l}\text { This study } \\
\text { (second PCR) }\end{array}$ \\
\hline $\begin{array}{l}\text { TSnodZ3 } \\
\text { TSnodZ4 }\end{array}$ & $\begin{array}{l}\text { GGTTTCGGYGAYTGYCTBTGGTC } \\
\text { AATRTCTTCGCCRTTRCCRTGCC }\end{array}$ & $\begin{array}{l}\operatorname{nod} Z(40-62) \\
\operatorname{nod} Z(552-530)\end{array}$ & nodZII & $\begin{array}{l}2 \min 95^{\circ} \mathrm{C}, 35 \times \\
\left(45 \mathrm{~s} 94{ }^{\circ} \mathrm{C}, 30 \mathrm{~s}\right. \\
\left.53{ }^{\circ} \mathrm{C}, 1.5 \min 72{ }^{\circ} \mathrm{C}\right), \\
7 \min 72^{\circ} \mathrm{C}\end{array}$ & $\begin{array}{l}\text { Moulin et al. } \\
\text { (2004) }\end{array}$ \\
\hline $\begin{array}{l}\text { nifHF } \\
\text { nifHI } \neq\end{array}$ & $\begin{array}{l}\text { TACGGNAARGGSGGNATCGGCAA } \\
\text { AGCATGTCYTCSAGYTCNTCCA }\end{array}$ & $\begin{array}{l}\text { nifH }(25-50) \\
\text { nifH }(787-808)\end{array}$ & nifHII & $\begin{array}{l}2 \min 95{ }^{\circ} \mathrm{C}, 35 \times(1 \mathrm{~min} \\
94{ }^{\circ} \mathrm{C}, 45 \text { s } 60{ }^{\circ} \mathrm{C}, 2 \mathrm{~min} \\
\left.72{ }^{\circ} \mathrm{C}\right), 7 \min 72{ }^{\circ} \mathrm{C}\end{array}$ & $\begin{array}{l}\text { Laguerre et al. } \\
(2001)\end{array}$ \\
\hline
\end{tabular}

${ }^{\star}$ Mixtures of bases used at certain positions are given as: S, G or C; Y, C or T; R, A or G; N, A, T, C or G.

$\dagger$ For nod genes, primer positions correspond to sequences in B. japonicum USDA 110; for nifH, primer positions correspond to sequences in $R$. leguminosarum bv. trifolii.

$¥$ Primers also used for sequencing reaction.

§Complete sequence.

IIPartial sequence.

the fragments contained nodY/K and about $300 \mathrm{bp}$ of nodA. Finally, the nodY/K sequences of these five strains were approximately $300 \mathrm{bp}$ shorter and therefore only a 402-514 bp consensus fragment present in all strains was considered in the phylogenetic analysis.

The phylogenetic tree built with the partial sequences of nodA (272-277 bp) split the strains into six well-supported major clusters (I-VI) (Fig. 1; Table 3). Cluster I grouped together 25 SEMIA strains and the reference/type strains used in this study (Fig. 1) with bootstrap support of $66 \%$. Six subclusters (I.1 to I.6) were formed in cluster I. Subcluster I.1 included seven SEMIA strains of distinct geographic origin, all symbionts of Glycine max, and also the type/reference strains of B. japonicum USDA $6^{\mathrm{T}}$ and USDA 110. Subcluster I.2 included strain SEMIA 5062 isolated from soybean in Brazil and the type strain of $B$. yuanmingense CCBAU $10071^{\mathrm{T}}$, isolated from Lespedeza cuneata in China; however, bootstrap support was low (46\%). Subcluster I.3 included strains SEMIA 6059 from Psophocarpus tetragonolobus (USA), SEMIA 656 from Neonotonia wightii (Brazil) and SEMIA 6077 from Stylosanthes sp. (Brazil). Five SEMIA strains of distinct tropical legumes formed subcluster I.4: SEMIA 6028 from Desmodium uncinatum (Zimbabwe), three Brazilian strains (SEMIA 6146 from Centrosema sp., SEMIA 6148 from N. wightii and SEMIA 6069 from Leucaena leucocephala) and strain SEMIA 6093 from Aeschynomene americana (USA). Subcluster I.5 was formed by the Brazilian strains SEMIA 6152 from Calopogonium sp. and SEMIA 6160 from Albizia lebbeck. Seven SEMIA strains related to the type strains of B. elkanii and B. pachyrhizi (Supplementary Fig. S1) were included in subcluster I.6; the majority were symbionts of Glycine max, but there were also symbionts of other legumes.

Cluster II of the nodA tree included strain SEMIA 6319 isolated from Arachis hypogaea in Bolivia and Bradyrhizobium sp. Lcamp8 isolated from Lupinus campestris in Mexico (Fig. 1; Table 3). Cluster III included SEMIA 6101 from Dalbergia nigra, SEMIA 6440 from Arachis pintoi and SEMIA 6099 from Dimorphandra exaltata, all isolated in Brazil. Cluster IV included strain SEMIA 6374, a symbiont of Arachis pintoi of unknown origin, and Bradyrhizobium sp. CH2309, a symbiont of Lupinus albescens from Brazil. Cluster V included SEMIA 6156 from Crotalaria spectabilis (Brazil) and SEMIA 928 from Lupinus sp. (site of isolation unknown), in addition to Bradyrhizobium sp. Lpol9, Ch2355, USDA 3505, FTA7, BLUH1 and ICED, all symbionts of Lupinus species of distinct geographic origin (from the study of Stępkowski et al., 2007). Finally, cluster VI included five SEMIA strains, all symbionts of Acacia mearnsii, and also Bradyrhizobium sp. USDA 3475 from Acacia melanoxylon, all isolated in Brazil. In subclusters I.4 and I.5, and in cluster III, symbionts of legumes of the subfamily Papilionoideae were interspersed with other members of the subfamilies Mimosoideae (subclusters I.5 and I.4) and Caesalpinioideae (cluster III). Cluster VI comprised predominantly symbionts of Acacia mearnsii, 
subfamily Mimosoideae, with bootstrap support of $100 \%$. The other cluster and subclusters had symbionts of several species of the subfamily Papilionoideae (Fig. 1; Tables 1 and 3). Overall, the Bradyrhizobium partial sequences of nodA were genetically distant from other rhizobial nodA sequences (Mesorhizobium loti MAFF303099, Rhizobium etli CFN42 ${ }^{\mathrm{T}}$, Rhizobium sp. NGR234, Sinorhizobium fredii HH103, Sinorhizobium meliloti 1021, Rhizobium leguminosarum bv. viciae 3841 and Rhizobium leguminosarum bv. trifolii WSM1325) included in the phylogenetic tree for comparison.

The consensus region of $402-514 \mathrm{bp}$ of $n o d Y / K$ of the same 37 strains used in the nodA tree was analysed and the resulting phylogenetic tree had a clear correlation with the nodA tree (Fig. 2; Table 3). Some type and reference strains used in the phylogenetic tree of nodA were not included in the $n o d Y / K$ tree, because their sequences were not available in GenBank. Furthermore, nod $Y / K$ genes are found exclusively in Bradyrhizobium, so members of other rhizobial genera could not be included for comparison. In the nodY/ $K$ tree, the strains also split into six clusters, but three of them were represented by only one strain (SEMIA strains 5062, 6374 and 6319). Reference/type strains were positioned exclusively in cluster I: in subcluster I.1, seven SEMIA strains grouped with $B$. japonicum USDA 110 (bootstrap support of $83 \%$ ); and in subcluster I.5, seven other SEMIA strains grouped with B. elkanii USDA $76^{\mathrm{T}}$ and USDA 94 (bootstrap support of $79 \%$ ). All strains in subcluster I.1 and five of the seven strains in subcluster I.5 were symbionts of Glycine max. As observed in the nodA tree, symbionts of legumes of the subfamily Papilionoideae were interspersed with those of the subfamilies Mimosoideae (subclusters I.4 and I.5) and Caesalpinioideae (cluster III), whereas symbionts of Acacia mearnsii, subfamily Mimosoideae, were all grouped in cluster VI, with bootstrap support of $99 \%$.

Amplification of the nodZ region was achieved with 35 strains using the TSnodZ primers (Table 2), and fragments of $427-433 \mathrm{bp}$ were obtained and analysed. The three strains that did not amplify with the primer for the nodD-nodB region, SEMIA strains 6014, 6192 and 6434, amplified successfully with TSnodZ primers. In contrast, the five symbionts of Acacia mearnsii that clustered in the nodA and $n o d Y / K$ trees did not amplify with primers for the nodZ region. In general, clustering in the tree built with nodZ was very similar to clustering in the trees built with the nodA and nodY/K genes (Fig. 3; Table 3). One exception was SEMIA 6434, which did not amplify with nodA and nodY/K, and grouped with SEMIA 6374 in cluster VI. Another exception relied on SEMIA strains 6014 and 6192, which also failed to amplify with primers for nodA and $\operatorname{nod} Y / K$, and occupied isolated positions in the nodZ tree.

\section{Nitrogen fixation nifH gene}

PCR amplification of the nifH gene resulted in fragments of 671-678 bp for all 40 SEMIA strains. As mentioned above, the PCR product of SEMIA 6434 had to be cloned before sequencing and two different fragments of similar sizes were obtained and analysed, showing similarity of $97.35 \%$. The phylogenetic tree built with the nifH gene was congruent with trees built with the nodA and nodY/K genes and strains that did not amplify for those genes occupied isolated clusters in the nifH tree (Fig. 4; Table 3). The five symbionts of Acacia mearnsii were included in cluster IX of the nifH tree. All nifH sequences of Bradyrhizobium SEMIA strains showed great phylogenetic distance from those of other genera, such as Rhizobium and Klebsiella, and also from the photosynthetic Bradyrhizobium sp. strain BTAi1.

\section{Southern hybridization of $\operatorname{nod} Y / K, \operatorname{nod} A$ and nodZ genes}

Hybridization was performed with SEMIA strains 6014, 6192 and 6434, which did not amplify with the TSnodD11a/TSnodB1 primers. Probes for nodY/K and nodA were prepared with $B$. japonicum USDA $6^{\mathrm{T}}$ and $B$. elkanii USDA $76^{\mathrm{T}}$ and no hybridization was observed for SEMIA strains. For the nodZ gene, probes were also prepared with strains USDA $6^{\mathrm{T}}$ and USDA $76^{\mathrm{T}}$; no hybridization was observed with SEMIA strains $6163,6164,6179,6186$ or 6187.

\section{Congruence of 16S rRNA and housekeeping genes with nodA, nod $Y / K$ and nifH}

Congruence between the 16S rRNA and housekeeping genes with nod and nif trees was low (Table 3). For example, strains found in cluster I of the nodA tree were positioned in clusters I and II of the 16S rRNA (Table 3). The only exception observed was for strains positioned in clusters VI of nodA (Fig. 1), IV of nodY/K (Fig. 2) and IX of nifH (Fig. 4), that formed subclusters I.5 of the 16S rRNA and I.8 of the housekeeping trees (Supplementary Fig. S1). Interestingly, all strains belonging to these groups are symbionts of Brazilian Acacia species (Table 1).

\section{DISCUSSION}

Bradyrhizobium is an intriguing genus of bacteria that probably originated in tropical regions and most strains used in this study originated from legumes growing in South America, a continent that was isolated for almost 70 million years and is known to have highly diverse legume flora. Additionally, in South America, legumes showed a high level of diversity by the end of the Palaeocene period, forming one of the most species-rich groups among angiosperms in the early neotropical forest 58-60 million years ago. This might indicate that the Leguminosae have evolved in South America and/or South America was the place of their initial differentiation into three subfamilies (Sprent, 2007). Accordingly, based on ribosomal and other housekeeping genes, apparently there are also many more 


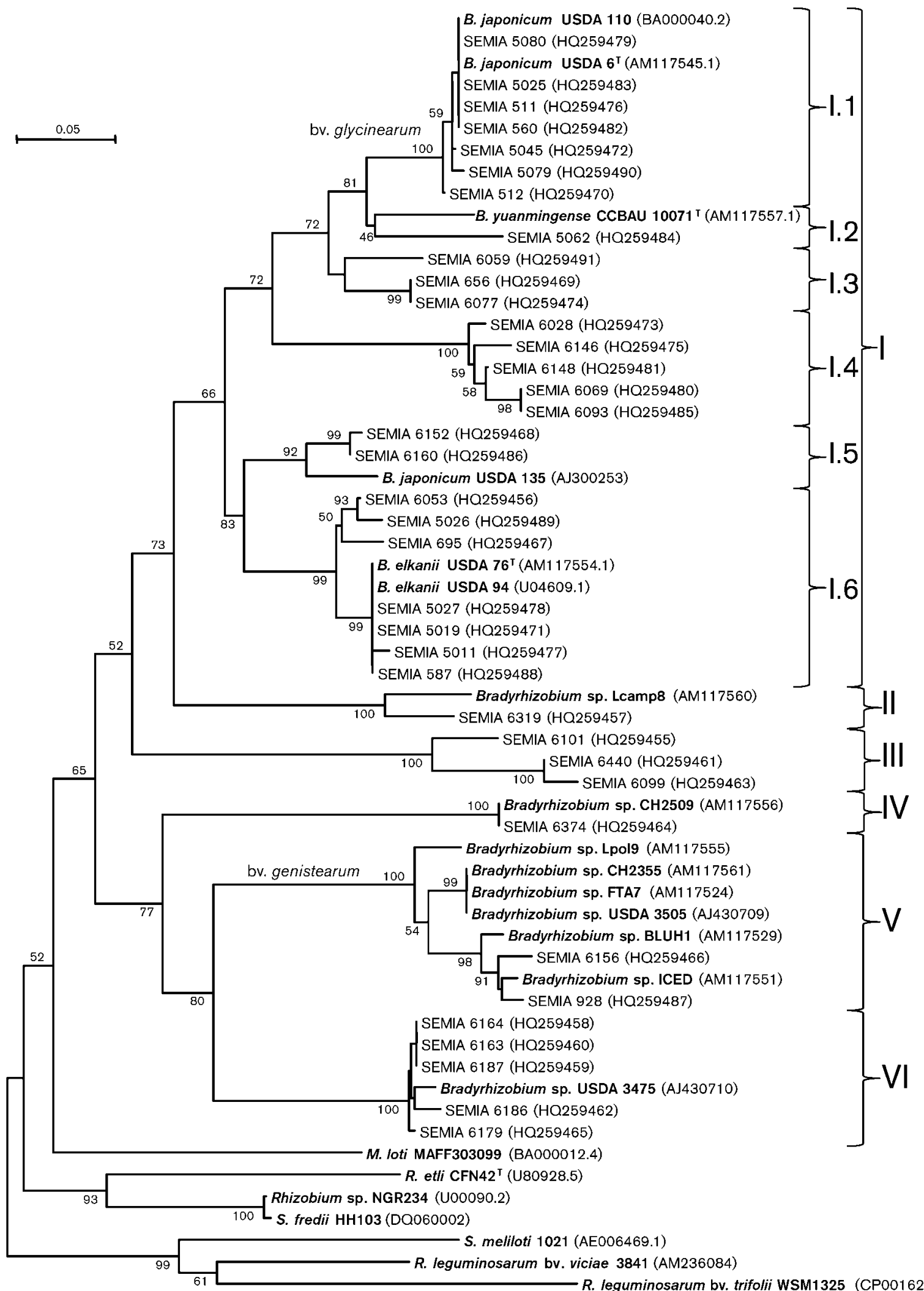

R. leguminosarum bv. trifolii WSM1325 (CP001623)

varieties of Bradyrhizobium in tropical and subtropical regions than in temperate regions (Vinuesa et al., 2008), but knowledge about nodulation and nitrogen fixation genes is still very poor. Our study, therefore, aimed to increase current knowledge by providing data for 40 bradyrhizobial strains. 
Fig. 1. Phylogenetic relationships of 37 Bradyrhizobium SEMIA and type/reference strains based on nodA partial sequences. Type/reference strains are highlighted in bold. Phylogeny was inferred using the neighbour-joining method. The percentages of replicate trees in which the associated taxa clustered together in the bootstrap test (1000 replicates) are shown next to branches. The tree is drawn to scale, with branch lengths in the same units as those of the evolutionary distances used to infer the phylogenetic tree. Evolutionary distances were computed using the maximum composite likelihood method and are given as the number of base substitutions per site. Positions containing gaps and missing data were eliminated from the dataset (complete deletion option). Phylogenetic analyses were conducted in MEGA4.

The hypothesis of the monophyletic origin of nodA in Bradyrhizobium has been raised from studies in which several strains fit into a well-defined phylogenetic group, in some cases showing correlation with the geographic origin of the host (Stępkowski et al., 2007; Steenkamp et al., 2008). Our results also support this theory, as the 37 SEMIA strains of Bradyrhizobium were clearly separate from members of other rhizobial genera. Additionally, studies of the evolution of the nodA gene in the genus Bradyrhizobium have indicated that the gene can be longer in this genus than in other rhizobial genera. In Bradyrhizobium strains isolated from various leguminous genera in several geographic regions, nodA coded for 209-211 amino acids, whereas in Mesorhizobium, Rhizobium and Sinorhizobium, the gene products were 195-198 amino acids (Moulin et al., 2004; Stępkowski et al., 2007). The loss of the $\mathrm{N}$-terminal region of the NodA protein in other rhizobial genera suggests that the nodA gene may be undergoing an evolutionary progression towards a shorter sequence (Moulin et al., 2004), which also gives support to the theory that nitrogen fixation in Bradyrhizobium could be ancestral to that in other rhizobia (Norris, 1965; Turner \& Young, 2000; Lloret \& MartínezRomero, 2005). Although giving support to the monophyletic origin hypothesis, it should be noted that high diversity was detected among phylogenetic groups of Bradyrhizobium, therefore indicating that other strains from different geographic origins should be analysed to confirm this evolutionary hypothesis.

The previously reported correlation between nodA phylogenetic clusters and symbiotic host (Moulin et al., 2004; Stępkowski et al., 2005, 2007) was also observed in our study. In previous studies, the monophyletic nodA tree was split in six major branches referred to as clades I-VI. Clades I and IV comprised strains isolated from legumes native to Australia. Clade II included Genisteae and serradella isolates mainly of European origin, clade III was a large group comprising nodA sequences of mainly subtropical strains and clade VI included photosynthetic rhizobia. Similarly, in this study the nodA phylogenetic tree split the strains in distinct groups (clusters I-VI) and, in some cases, clear correlations between the clusters and the host or biogeography were observed, e.g. subcluster I.1 comprised symbionts of Glycine max. The presence of this specific group for Glycine max suggests the predominance of a specific nodA gene in strains related to $B$. japonicum (Supplementary Fig. S1) and the biovar glycinearum could be suggested for these strains. Subclusters I.2-I.6 and clusters II and III were intermixed with a variety of symbionts, but all were of pantropical origin.

Similarly to previous reports, cluster $\mathrm{V}$ included symbionts of Lupinus species (Moulin et al., 2004; Stępkowski et al., $2005,2007)$ and for these strains the biovar genistearum has been suggested (Stępkowski et al., 2007). However, in our study, strain SEMIA 6156, a symbiont of Crotalaria spectabilis, was also included in this cluster, although the ability of this strain to also nodulate Lupinus species has not yet been investigated.

A specific cluster was also observed for strains that were symbionts of Acacia mearnsii and included Bradyrhizobium sp. USDA 3475, a symbiont of Acacia melanoxylon from Brazil, positioned in cluster VI in the nodA tree; these strains were related to the Australian cluster (Acacia mearnsii is native to the temperate zone of Australia). Similar clusters were also reported by Moulin et al. (2004), who defined a cluster (I) that was related to the Australian group, with symbionts of Acacia species.

Another interesting observation is that the results from our study indicate that some strains, such as the isolates from Arachis species, are unique to South America, whereas others show affinity to the Australian or European clades. The peanut strains show that this promiscuous legume is nodulated by various bradyrhizobia. It is of note that none of these strains show similarity to the peanut strains from Africa described by Steenkamp et al. (2008). This might indicate differences between the Australian Acacia species, which seem to favour their 'Australian' microsymbionts, whereas peanut forms nodules with rhizobia that are available in the soil.

Clusters similar to those in the nodA tree were also observed in the phylogenetic tree built with nodY/K. Unique features within Bradyrhizobium are the presence of nodY in $B$. japonicum (420 bp) (Nieuwkoop et al., 1987), nodK in B. elkanii (402 bp) (Dobert et al., 1994) and nodY/K in Bradyrhizobium sp. (a symbiont of Parasponia, a nonlegume; 411 bp) (Scott, 1986). Dobert et al. (1994) observed that the similarity between nodY of B. japonicum USDA 123 and nodK of B. elkanii USDA 94 was only $49 \%$ and, in our study, the lowest similarity (36\%) was observed between SEMIA 6374 (from Arachis pintoi) and the other Bradyrhizobium strains analysed. The nodY/K putative gene is found downstream of nodD1 and upstream and coregulated with the nodABC operon (Nieuwkoop et al., 1987; Dobert et al., 1994; Scott, 1986). Unfortunately, 


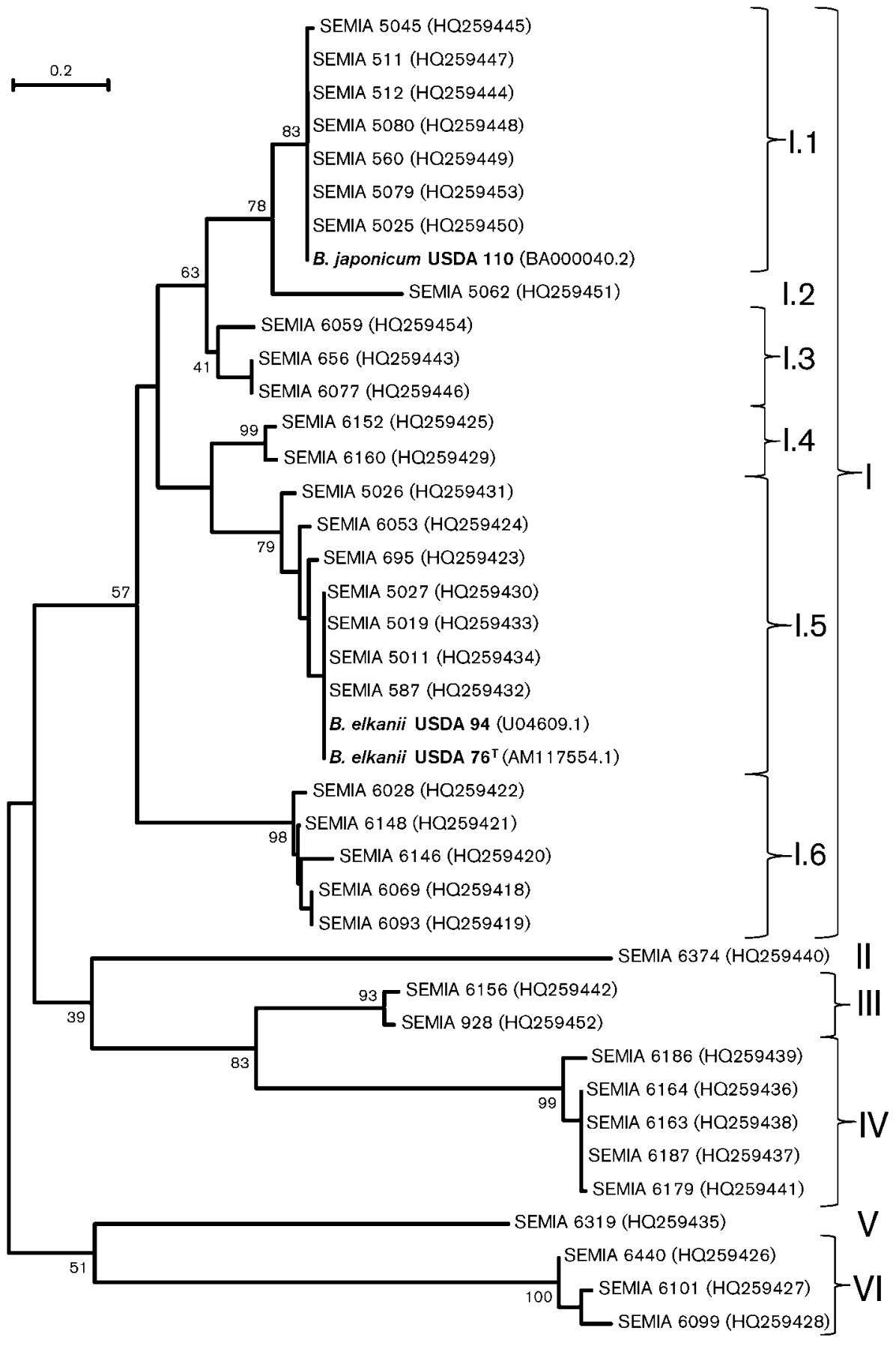

Fig. 2. Phylogenetic relationships of 37 Bradyrhizobium SEMIA and type/reference strains based on nodY/K partial sequences. See legend to Fig. 1 for further details.

despite being broadly found in a variety of Bradyrhizobium strains, including those reported in our study, the role of nod $Y / K$ is still poorly understood, with no indication that it is a protein-coding region; therefore, nod $Y / K$ may be regarded as a nodD-nodA intergenic (non-coding) region.

In a previous study, Sterner \& Parker (1999) used the sequence similarity of nodY and nodK to distinguish strains of B. japonicum and B. elkanii, but a higher diversity of these genes was subsequently reported, with evidence of distinct phylogenetic groups (You et al., 2002; Stępkowski et al., 2003). In our study, a relationship was found between the nod $Y / K$ clusters and the two large 16S rRNA groups defined by Menna et al. (2009a), each comprising several Bradyrhizobium species. However, a very low 


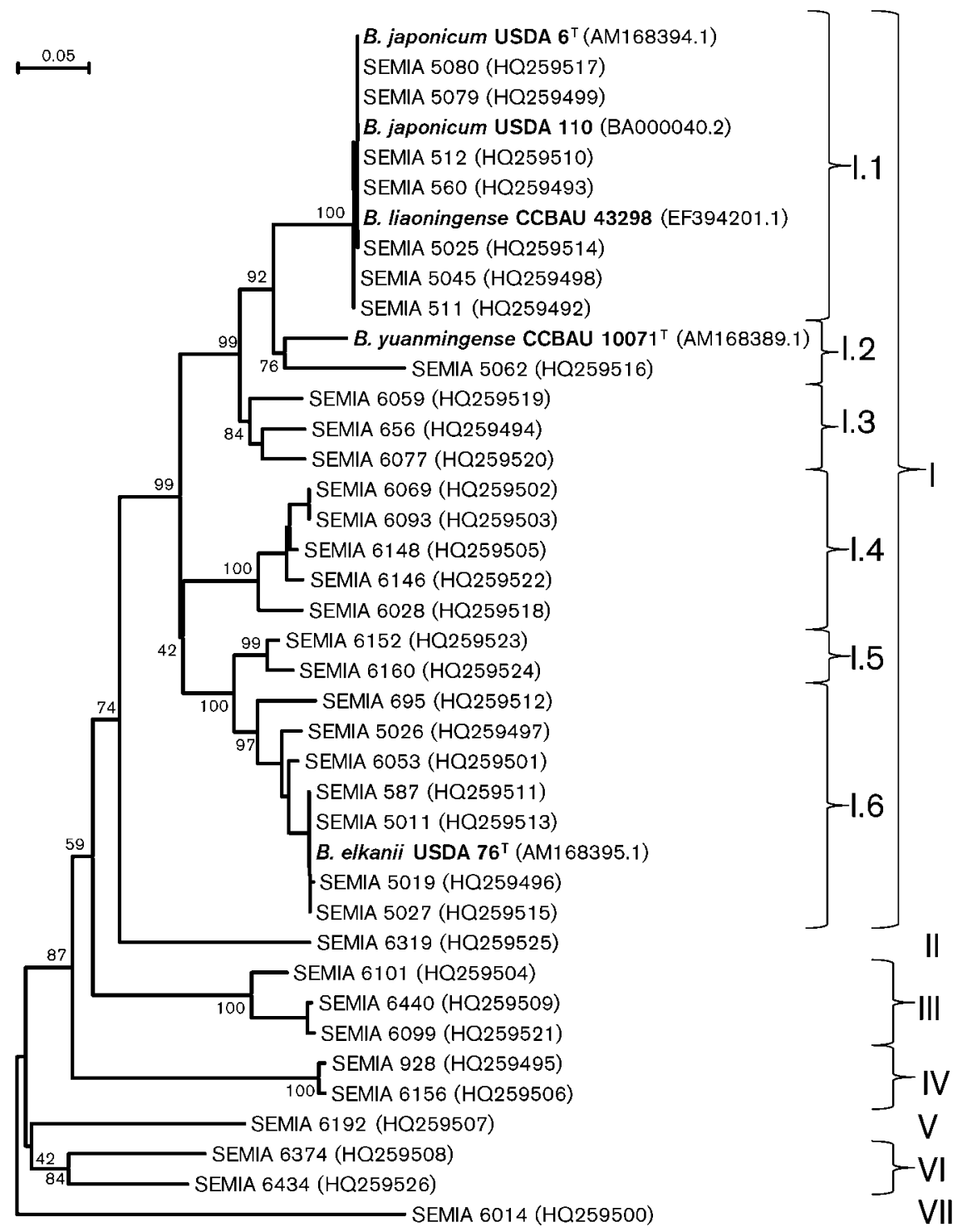

Fig. 3. Phylogenetic relationships of 35 Bradyrhizobium SEMIA and type/reference strains based on nodZ partial sequences. See legend to Fig. 1 for further details.

congruence was found between the nodY/K of our study and the 16S rRNA subgroups reported by Menna et al. (2009a). In addition, a far greater diversity was observed in the phylogeny of nodY/K compared to the $16 \mathrm{~S}$ rRNA gene.

However, considering the nod $Y / K$ tree, several groups have shown that no clear correlation with host plant, e.g. SEMIA strains 6152 (Calopogonium) and 6160 (Albizia), symbionts from the subfamilies Papilionoideae and Mimosoideae, respectively, were grouped in subcluster I.4. However, other groups were strongly related to the symbionts, e.g. subcluster I.1 had exclusively soybean symbionts, classified as $B$. japonicum in the $16 \mathrm{~S}$ rRNA gene tree, and cluster IV included symbionts of Acacia mearnsii (Mimosoideae). It is of note that a shorter fragment of nodY/K and nodA, which was about $300 \mathrm{bp}$ shorter than in the other Bradyrhizobium strains from this study, was observed in cluster VI. The symbiosis is thought to have evolved from Caesalpinioideae to Mimosoideae and then to Papilionoideae, because nodulation frequency progresses from uncommon to very common in these subfamilies (Sprent, 2007). It is possible that the shorter nodY/K in Acacia species evolved specifically from an ancestor of the subfamily Mimosoideae and has been maintained by vertical transfer.

Neither nodA nor nodY/K was detected by amplification or hybridization in three strains: SEMIA 6014 from Stylosanthes guianensis (isolated in Peru), SEMIA 6192 from Tipuana tipu (isolated in Brazil) and SEMIA 6434 from Inga sp. (origin not known). Until now, the absence 




Fig. 4. Phylogenetic relationships of 40 Bradyrhizobium SEMIA and type/reference strains based on nifH partial sequences. See legend to Fig. 1 for further details. 
of the common nodABC genes and of nodY/K has been reported only for photosynthetic Bradyrhizobium strains BTAil and ORS 278, symbionts from Aeschynomene stem nodules (Giraud et al., 2007). The absence of nodA and nodY/K in these three SEMIA strains could be attributed to the specificity of the primer used in this study and the high diversity of the genes in these Bradyrhizobium strains. However, our results could also indicate that an alternative mechanism for initiating transcription of nodulation genes is not exclusive to the stem-nodulating group.

nodZ gene clustering has also shown high congruence with the trees built with nodA and nodY/K sequences, except that $\operatorname{nodZ}$ was present in SEMIA strains 6192, 6434 and 6014 , which had no detectable nodA or $\operatorname{nodY/K}$, and also that $n o d Z$ was absent in the group of five symbionts from Acacia mearnsii. nodZ is an unusual gene in comparison to other common nodulation genes such as $\operatorname{nod} A B C$ as its expression is constitutive and independent of nodD (Stacey et al., 1994). Chemical analysis of nodZ mutants of B. japonicum has suggested that NodZ is essential for fucosylation of the terminal reducing $\mathrm{N}$-acetylglucosamine of the lipo-chitin oligosaccharides (LCOs) of Nod factors (Stacey et al., 1994). nodZ was also shown to determine host specificity in a study where the transference of the nod $Z$ of $B$. japonicum to Rhizobium leguminosarum bv. viciae led to the biosynthesis of LCOs fucosylated on C6 of the reducingterminal $\mathrm{N}$-acetylglucosamine, extending the host range to several tropical legumes, including Macroptilium, Glycine, Vigna and Leucaena (López-Lara et al., 1996).

The high diversity of nodZ detected in our study, in addition to the variability observed in Bradyrhizobium from other geographic origins (Steenkamp et al., 2008) gives support to the hypothesis that variability in the decorated nodulation factors might represent an important adaptation strategy, enabling nodulation of a variety of legumes. On the other hand, the absence of nodZ in the symbionts of Acacia species might indicate that a specific fucosylation of the LCOs may not be necessary for nodulation of the host plant, probably due to a close coevolution of symbiotic partners.

In contrast to the nodulation genes, nif genes are found in all diazotrophic bacteria; however, it is still not clear if, from an evolutionary point of view, they are part of the symbiotic genome or the 'normal' bacterial genome (Young \& Haukka, 1996). Previous studies with Rhizobium have shown a close phylogenetic relationship between nifH and $16 \mathrm{~S}$ rRNA genes, leading to the suggestion of a common evolutionary history for both genes (Hennecke et al., 1985; Young, 1992). However, this hypothesis was not supported by a further study by Eardly et al. (1992), suggesting that the genes located in the symbiotic plasmid may move across chromosomal backgrounds by horizontal transfer. In $B$. japonicum, the nifH gene and the nodulation genes are found in a symbiotic island flanked by insertion sequence elements, with a high capacity for horizontal gene transfer (Kaluza et al., 1985; Kaneko et al., 2002). Indeed, previous studies by our group have pointed out high rates of horizontal transfer of the symbiotic islands of Bradyrhizobium, even under regular field conditions (Barcellos et al., 2007; Batista et al., 2007). In the present study, the nifH tree was highly congruent with trees built with the nodulation genes nodY/K, nodA and nodZ, and, as in nodA analysis, indicates a monophyletic origin of the nifH gene, but which, through several episodes of vertical and horizontal gene transfer, has resulted in the high level of genetic diversity observed today.

Several studies have shown that the diversity of housekeeping genes in Bradyrhizobium is much higher than initially thought (e.g. Bala et al., 2003; Menna et al., 2009a, b), but as we pointed out before there is still little information about the diversity of nodulation and nitrogen-fixation genes within this genus. By comparing the phylogenies of nodulation and housekeeping genes of 22 Bradyrhizobium strains isolated from cowpea and peanut, Steenkamp et al. (2008) reported that overall phylogenies for the nodulation genes were incongruent with that inferred from the core genome genes, suggesting that horizontal gene transfer significantly influences the evolution of the root-nodule bacteria. Stępkowski et al. (2005) have also suggested that this horizontal gene transfer may be influenced by the host plant. Erratic distribution of nodulation and nitrogenfixation genes among rhizobial species and lineages has also been highlighted (e.g. Laguerre et al., 2001; Mutch et al., 2003) and, altogether, the data reinforce the key role of horizontal gene transfer in genome adaptation (Ochman et al., 2000; Koonin et al., 2001). We believe that our study describes the highest diversity of nod and nif genes in Bradyrhizobium reported so far, with several well-defined groups formed with nodY/K and nodA genes and with nifH, in addition to a few strains occupying isolated positions. In comparison to the $16 \mathrm{~S}$ rRNA and housekeeping gene trees, the congruence of the clusters and subclusters formed was very poor, except for groups formed for the symbionts of Acacia mearnsii. Three aspects of our study are particularly noteworthy: i) use of two sets of symbiotic genes, nodulation (nodY/K, nodA and nodZ) and nitrogen fixation (nifH), distantly located in the symbiosis island of $B$. japonicum (Kaneko et al., 2002); ii) the congruence of all nod and nif trees found in our study; iii) the clustering of all Bradyrhizobium in a large group that clearly differs from other rhizobial species in the analyses of nodA and nifH (except for strain BTAil in the latter case). Considering these three points, our results give support to the monophyletic origin of the symbiotic island that may have spread to several Bradyrhizobium strains, both by vertical and horizontal gene transfer, generating a high level of diversity. From our results, we may also draw other important conclusions and hypotheses. Firstly, that the absence of nodY/K and nodA in three Bradyrhizobium SEMIA strains isolated from root nodules of Stylosanthes, Tipuana and Inga should be further investigated, as it might indicate whether the absence of the common operon nodY/KABC is not unique to some photosynthetic rhizobia. Another hypothesis is that the high diversity of the host-specific gene nodZ might indicate 
Table 3. Phylogenetic grouping formed in the trees built with the following genes: $16 \mathrm{~S}$ rRNA, housekeeping genes (Menna et al., 2009a), and the genes from this study, nodA, nodYIK, nodZ and nifH

Given in the order: large 16S rRNA group, nodA and nifH. NA, Not analysed; Isol, isolated; NAmp, not amplified; ND, not defined.

\begin{tabular}{|c|c|c|c|c|c|c|c|c|c|c|c|c|}
\hline \multirow[t]{2}{*}{ Strain } & \multicolumn{2}{|c|}{ 16S rRNA } & \multicolumn{2}{|c|}{ Housekeeping } & \multicolumn{2}{|c|}{$\operatorname{nod} A$} & \multicolumn{2}{|c|}{ nodY/K } & \multicolumn{2}{|c|}{$\operatorname{nod} Z$} & \multicolumn{2}{|c|}{ nifH } \\
\hline & Cluster & Subcluster & Cluster & Subcluster & Cluster & Subcluster & Cluster & Subcluster & Cluster & Subcluster & Cluster & Subcluster \\
\hline SEMIA 511 & I & I. 3 & I & I.7 & I & I. 1 & I & I. 1 & I & I. 1 & I & I. 1 \\
\hline SEMIA 512 & I & 1.4 & I & I.7 & I & I.1 & I & I.1 & I & I.1 & I & I.1 \\
\hline SEMIA 560 & I & I.1 & I & I. 3 & I & I.1 & I & I. 1 & I & I. 1 & I & I. 1 \\
\hline SEMIA 5025 & I & I.3 & I & $\mathrm{I} .1$ & I & I. 1 & I & I. 1 & I & I. 1 & I & I. 1 \\
\hline SEMIA 5045 & I & I. 2 & I & I.7 & I & I. 1 & I & I.1 & I & I. 1 & I & I. 1 \\
\hline SEMIA 5079 & I & I. 4 & I & I.7 & I & I. 1 & I & I. 1 & I & I. 1 & I & I.1 \\
\hline SEMIA 5080 & I & I.6 & I & I.6 & I & I. 1 & I & I.1 & I & I. 1 & I & I. 1 \\
\hline USDA 110 & I & I.6 & I & I.6 & I & I.1 & I & I.1 & I & I. 1 & I & I.1 \\
\hline USDA $6^{\mathrm{T}}$ & I & I. 4 & I & I.7 & I & I. 1 & NA & NA & I & I. 1 & NA & NA \\
\hline CCBAU $10071^{\mathrm{T}}$ & I & I. 3 & I & $\mathrm{I} .2$ & I & I. 2 & NA & NA & I & I. 2 & Isol & Isol \\
\hline SEMIA 5062 & I & I. 2 & I & I. 1 & I & I. 2 & I & I. 2 & I & I. 2 & I & I. 2 \\
\hline SEMIA 0656 & I & I. 8 & I & I. 4 & I & I. 3 & I & I. 3 & I & I. 3 & I & I. 3 \\
\hline SEMIA 6059 & I & I. 6 & I & I. 6 & I & I. 3 & I & I. 3 & I & I. 3 & I & I. 3 \\
\hline SEMIA 6077 & I & I. 8 & I & I. 2 & I & I. 3 & I & I. 3 & I & I. 3 & I & I. 3 \\
\hline SEMIA 6028 & II & II. 2 & II & II. 3 & I & I. 4 & I & I.6 & I & I. 4 & I & I. 4 \\
\hline SEMIA 6069 & II & II.1 & II & II. 3 & I & I. 4 & I & I.6 & I & I. 4 & I & I. 4 \\
\hline SEMIA 6093 & II & Isol & II & II. 3 & I & I. 4 & I & I.6 & I & I. 4 & I & I. 4 \\
\hline SEMIA 6146 & II & II. 2 & II & II. 2 & I & I. 4 & I & I. 6 & I & I. 4 & I & I. 4 \\
\hline SEMIA 6148 & II & II. 2 & Isol & Isol & I & I. 4 & I & I.6 & I & I.4 & I & I.4 \\
\hline SEMIA 6152 & II & II.1 & II & II. 3 & I & I. 5 & I & I. 4 & I & I. 5 & I & I. 5 \\
\hline SEMIA 6160 & II & II. 2 & II & II. 3 & I & I. 5 & I & I. 4 & I & I. 5 & I & I. 5 \\
\hline USDA 135 & I & I. 3 & NA & NA & I & I. 5 & NA & NA & NA & NA & NA & NA \\
\hline SEMIA 0587 & II & II. 2 & II & II.1 & I & I. 6 & I & I. 5 & I & I. 6 & I & I. 6 \\
\hline SEMIA 0695 & II & II. 2 & II & Isol & I & I.6 & I & I.5 & I & I.6 & I & I.6 \\
\hline SEMIA 5011 & II & II. 2 & II & II.1 & I & I. 6 & I & I.5 & I & I. 6 & I & I.6 \\
\hline SEMIA 5019 & II & II. 2 & II & II.1 & I & I.6 & I & I.5 & I & I.6 & I & I.6 \\
\hline SEMIA 5026 & II & II. 2 & II & II.1 & I & I.6 & I & I.5 & I & I.6 & I & I.6 \\
\hline SEMIA 5027 & II & II. 2 & II & II.1 & I & I.6 & I & I.5 & I & I.6 & I & I.6 \\
\hline SEMIA 6053 & II & II. 2 & II & II. 3 & I & I. 6 & I & I.5 & I & I.6 & I & I.6 \\
\hline USDA $76^{\mathrm{T}}$ & II & II. 2 & II & II.1 & I & I. 6 & I & I. 5 & I & I. 6 & I & I. 6 \\
\hline USDA 94 & NA & NA & NA & NA & I & I. 6 & I & I. 5 & NA & ND & NA & NA \\
\hline SEMIA 6319 & I & I. 3 & I & I. 2 & II & ND & V & ND & II & II & II & ND \\
\hline NC92 & NA & NA & NA & NA & II & ND & NA & NA & NA & NA & NA & NA \\
\hline SEMIA 6099 & II & II. 2 & II & II. 3 & III & ND & VI & ND & III & ND & III & ND \\
\hline SEMIA 6101 & II & II.1 & II & II. 2 & III & ND & VI & ND & III & ND & III & ND \\
\hline
\end{tabular}


Table 3. cont.

\begin{tabular}{|c|c|c|c|c|c|c|c|c|c|c|c|c|}
\hline \multirow[t]{2}{*}{ Strain } & \multicolumn{2}{|c|}{ 16S rRNA } & \multicolumn{2}{|c|}{ Housekeeping } & \multicolumn{2}{|c|}{$\operatorname{nod} A$} & \multicolumn{2}{|c|}{ nod $Y / K$} & \multicolumn{2}{|c|}{$\operatorname{nod} Z$} & \multicolumn{2}{|c|}{ nifH } \\
\hline & Cluster & Subcluster & Cluster & Subcluster & Cluster & Subcluster & Cluster & Subcluster & Cluster & Subcluster & Cluster & Subcluster \\
\hline SEMIA 6440 & II & II. 2 & II & II. 3 & III & ND & VI & ND & III & ND & III & ND \\
\hline SEMIA 6374 & I & I. 8 & I & I. 4 & IV & ND & II & ND & IV & ND & VII & ND \\
\hline SEMIA 6014 & I & I.7 & I & I.4 & NAmp & NAmp & NAmp & NAmp & VII & ND & $\mathrm{V}$ & ND \\
\hline SEMIA 6192 & I & I. 8 & I & I. 3 & NAmp & NAmp & NAmp & NAmp & $\mathrm{V}$ & ND & VI & ND \\
\hline SEMIA 6434 & I & I. 8 & I & Isol & NAmp & NAmp & NAmp & NAmp & IV & ND & VIII & ND \\
\hline LMG $18230^{\mathrm{T}}$ & I & I. 3 & I & I.1 & NA & NA & $\mathrm{NA}$ & $\mathrm{NA}$ & NA & $\mathrm{NA}$ & I & I. 1 \\
\hline CCBAU 43298 & NA & NA & NA & NA & NA & NA & NA & ND & I & I.1 & NA & ND \\
\hline BTA- $1^{\mathrm{T}}$ & NA & NA & NA & NA & NA & NA & NA & NA & NA & NA & IV & ND \\
\hline $\mathrm{BC}-\mathrm{C} 2^{\mathrm{T}}$ & I & I.1 & $\mathrm{NA}$ & NA & NA & NA & NA & NA & NA & NA & NA & NA \\
\hline PL7HG1 $^{\mathrm{T}}$ & Isol & - & NA & NA & NA & NA & NA & NA & NA & NA & NA & NA \\
\hline PAC6 $8^{\mathrm{T}}$ & Isol & ND & NA & NA & NA & $\mathrm{NA}$ & NA & NA & NA & NA & NA & NA \\
\hline PAC $48^{\mathrm{T}}$ & II & II. 2 & NA & NA & NA & NA & NA & NA & NA & NA & NA & NA \\
\hline SEMIA 0928 & I & I. 1 & I & I. 5 & $\mathrm{~V}$ & ND & III & ND & IV & ND & IV & ND \\
\hline SEMIA 6156 & I & I.7 & I & I. 3 & $\mathrm{~V}$ & ND & III & ND & IV & ND & IV & ND \\
\hline USDA 3505 & I & Isol & $\mathrm{NA}$ & NA & $\mathrm{V}$ & ND & NA & NA & NA & NA & NA & NA \\
\hline SEMIA 6163 & I & I. 5 & I & Isol & VI & ND & IV & ND & NAmp & NAmp & IX & I. 8 \\
\hline SEMIA 6164 & I & I. 5 & I & I. 8 & VI & ND & IV & ND & NAmp & NAmp & IX & ND \\
\hline SEMIA 6179 & I & I. 5 & I & I. 8 & VI & ND & IV & ND & NAmp & NAmp & IX & ND \\
\hline SEMIA 6186 & I & I. .5 & I & I. 8 & VI & ND & IV & ND & NAmp & NAmp & IX & ND \\
\hline SEMIA 6187 & I & I. 5 & I & I. 8 & VI & ND & IV & ND & NAmp & NAmp & IX & ND \\
\hline USDA 3475 & I & I.6 & $\mathrm{NA}$ & NA & VI & ND & NA & NA & NA & $\mathrm{NA}$ & NA & NA \\
\hline
\end{tabular}


strategies of decoration of Nod factors to increase the host range, thus helping to explain the high diversity and poor relationship between strains assembled in cluster I (the pantropical cluster) and the host plant in the nod and nifH gene trees. Also interesting was the group of symbionts from Acacia mearnsii, which showed high congruence between the $16 \mathrm{~S}$ rRNA and housekeeping genes (dnaK, recA and $g \ln I I)$ and the $\operatorname{nod} Y / K$, nodA and nifH genes, in addition to a shorter $n o d Y / K$ and the absence of nodZ, strongly indicating a finely tuned co-evolution of the host plant and symbionts. The B. japonicum symbionts from soybean also showed high congruence of nod and nif genes with the 16S rRNA gene, albeit to a lesser extent. On the other hand, other groups deserve further study, such as the two symbionts of Arachis species, which occupied isolated positions in all nod and the nifH trees, with no relation with the core genes, apparently resulting from horizontal gene transfer. Therefore, despite reinforcing the theory of monophyletic origin of the symbiosis island in Bradyrhizobium, our study points out that events of horizontal gene transfer are common in a variety of groups, whereas, in others, vertical transfer represents the main genetic event, altogether contributing to the high level of diversity reported in this study.

\section{ACKNOWLEDGEMENTS}

The work was partially supported by $\mathrm{CNPq}$ (Conselho Nacional de Desenvolvimento Científico e Tecnológico, Brazil), CNPq-PNPD (558455/2008-5), CNPq/MCT/MAPA (577933/2008), CPNq-Universal (470162/2009) and CNPq-Repensa (562008/2010-1). P. M. has a postdoctoral fellowship from CNPq (558455/2008-5) and M.H. is also a research fellow from CNPq. The authors thank Dr Allan R. J. Eaglesham for suggestions on the manuscript.

\section{REFERENCES}

Angus, A. A. \& Hirsch, A. M. (2010). Insights into the history of the legume-betaproteobacterial symbiosis. Mol Ecol 19, 28-30.

Bala, A., Murphy, P. \& Giller, K. E. (2003). Distribution and diversity of rhizobia nodulating agroforestry legumes in soils from three continents in the tropics. Mol Ecol 12, 917-929.

Barcellos, F. G., Menna, P., da Silva Batista, J. S. \& Hungria, M. (2007). Evidence of horizontal transfer of symbiotic genes from a Bradyrhizobium japonicum inoculant strain to indigenous diazotrophs Sinorhizobium (Ensifer) fredii and Bradyrhizobium elkanii in a Brazilian Savannah soil. Appl Environ Microbiol 73, 2635-2643.

Batista, J. S. S., Hungria, M., Barcellos, F. G., Ferreira, M. C. \& Mendes, I. C. (2007). Variability in Bradyrhizobium japonicum and $B$. elkanii seven years after introduction of both the exotic microsymbiont and the soybean host in a cerrados soil. Microb Ecol 53, 270-284.

Broughton, W. J., Jabbouri, S. \& Perret, X. (2000). Keys to symbiotic harmony. J Bacteriol 182, 5641-5652.

Dixon, R. \& Kahn, D. (2004). Genetic regulation of biological nitrogen fixation. Nat Rev Microbiol 2, 621-631.

Dobert, R. C., Breil, B. T. \& Triplett, E. W. (1994). DNA sequence of the common nodulation genes of Bradyrhizobium elkanii and their phylogenetic relationship to those of other nodulating bacteria. $\mathrm{Mol}$ Plant Microbe Interact 7, 564-572.
Eardly, B. D., Young, J. P. W. \& Selander, R. K. (1992). Phylogenetic position of Rhizobium sp. strain Or 191, a symbiont of both Medicago sativa and Phaseolus vulgaris, based on partial sequences of the $16 \mathrm{~S}$ rRNA and nifH genes. Appl Environ Microbiol 58, 1809-1815.

Felsenstein, J. (1985). Confidence limits on phylogenies: an approach using the bootstrap. Evolution 39, 783-791.

Freiberg, C., Fellay, R., Bairoch, A., Broughton, W. J., Rosenthal, A. \& Perret, X. (1997). Molecular basis of symbiosis between Rhizobium and legumes. Nature 387, 394-401.

Giraud, E., Moulin, L., Vallenet, D., Barbe, V., Cytryn, E., Avarre, J. C., Jaubert, M., Simon, D., Cartieaux, F. \& other authors (2007). Legumes symbioses: absence of Nod genes in photosynthetic bradyrhizobia. Science 316, 1307-1312.

Göttfert, M., Röthlisberger, S., Kündig, C., Beck, C., Marty, R. \& Hennecke, H. (2001). Potential symbiosis-specific genes uncovered by sequencing a 410-kilobase DNA region of the Bradyrhizobium japonicum chromosome. J Bacteriol 183, 1405-1412.

Hedges, S. B. (1992). The number of replications needed for accurate estimation of the bootstrap P value in phylogenetic studies. Mol Biol Evol 9, 366-369.

Hennecke, H., Kaluza, K., Thöny, B., Fuhrmann, M., Ludwig, W. \& Stackebrandt, E. (1985). Concurrent evolution of nitrogenase genes and 16S rRNA in Rhizobium species and other nitrogen fixing bacteria. Arch Microbiol 142, 342-348.

Kaluza, K., Hahn, M. \& Hennecke, H. (1985). Repeated sequences similar to insertion elements clustered around the nif region of the Rhizobium japonicum genome. J Bacteriol 162, 535-542.

Kaneko, T., Nakamura, Y., Sato, S., Minamisawa, K., Uchiumi, T., Sasamoto, S., Watanabe, A., Idesawa, K., Iriguchi, M. \& other authors (2002). Complete genomic sequence of nitrogen-fixing symbiotic bacterium Bradyrhizobium japonicum USDA110. DNA Res 9, 189-197.

Kimura, M. (1980). A simple method for estimating evolutionary rates of base substitutions through comparative studies of nucleotide sequences. J Mol Evol 16, 111-120.

Koonin, E. V., Makarova, K. S. \& Aravind, L. (2001). Horizontal gene transfer in prokaryotes: quantification and classification. Annu Rev Microbiol 55, 709-742.

Laguerre, G., Nour, S. M., Macheret, V., Sanjuan, J., Drouin, P. \& Amarger, N. (2001). Classification of rhizobia based on nodC and nifH gene analysis reveals a close phylogenetic relationship among Phaseolus vulgaris symbionts. Microbiology 147, 981-993.

Lerouge, P., Roche, P., Faucher, C., Maillet, F., Truchet, G., Promé, J. C. \& Dénarié, J. (1990). Symbiotic host-specificity of Rhizobium meliloti is determined by a sulphated and acylated glucosamine oligosaccharide signal. Nature 344, 781-784.

Lloret, L. \& Martínez-Romero, E. (2005). [Evolution and phylogeny of rhizobia]. Rev Latinoam Microbiol 47, 43-60 (in Spanish).

López-Lara, I. M., Blok-Tip, L., Quinto, C., Garcia, M. L., Stacey, G., Bloemberg, G. V., Lamers, G. E., Lugtenberg, B. J., Thomas-Oates, J. E. \& Spaink, H. P. (1996). NodZ of Bradyrhizobium extends the nodulation host range of Rhizobium by adding a fucosyl residue to nodulation signals. Mol Microbiol 21, 397-408.

Menna, P., Hungria, M., Barcellos, F. G., Bangel, E. V., Hess, P. N. \& Martínez-Romero, E. (2006). Molecular phylogeny based on the $16 \mathrm{~S}$ rRNA gene of elite rhizobial strains used in Brazilian commercial inoculants. Syst Appl Microbiol 29, 315-332.

Menna, P., Barcellos, F. G. \& Hungria, M. (2009a). Phylogeny and taxonomy of a diverse collection of Bradyrhizobium strains based on multilocus sequence analysis of the $16 \mathrm{~S}$ rRNA gene, ITS region and glnII, recA, atpD and dnaK genes. Int J Syst Evol Microbiol 59, 2934-2950. 
Menna, P., Pereira, A. A., Bangel, E. V. \& Hungria, M. (2009b). repPCR of tropical rhizobia for strain fingerprinting, biodiversity appraisal and as a taxonomic and phylogenetic tool. Symbiosis 48, 120-130.

Moulin, L., Béna, G., Boivin-Masson, C. \& Stępkowski, T. (2004). Phylogenetic analyses of symbiotic nodulation genes support vertical and lateral gene co-transfer within the Bradyrhizobium genus. Mol Phylogenet Evol 30, 720-732.

Mutch, L. A., Tamimi, S. M. \& Young, J. P. W. (2003). Genotypic characterization of rhizobia nodulating Vicia faba from the soils of Jordan: a comparison with UK isolates. Soil Biol Biochem 35, 709-714.

Nieuwkoop, A. J., Banfalvi, Z., Deshmane, N., Gerhold, D., Schell, M. G., Sirotkin, K. M. \& Stacey, G. (1987). A locus encoding host range is linked to the common nodulation genes of Bradyrhizobium japonicum. J Bacteriol 169, 2631-2638.

Norris, D. O. (1965). Acid production by Rhizobium: a unifying concept. Plant Soil 22, 143-166.

Ochman, H., Lawrence, J. G. \& Groisman, E. A. (2000). Lateral gene transfer and the nature of bacterial innovation. Nature 405, 299-304.

Saitou, N. \& Nei, M. (1987). The neighbor-joining method: a new method for reconstructing phylogenetic trees. Mol Biol Evol 4, 406-425.

Sambrook, J. \& Russell, D. W. (2001). Molecular Cloning: a Laboratory Manual, 3rd edn. Cold Spring Harbor, NY: Cold Spring Harbor Laboratory Press.

Scott, K. F. (1986). Conserved nodulation genes from the non-legume symbiont Bradyrhizobium sp. (Parasponia). Nucleic Acids Res 14, 2905-2919.

Sprent, J. I. (2007). Evolving ideas of legume evolution and diversity: a taxonomic perspective on the occurrence of nodulation. New Phytol 174, 11-25.

Stacey, G., Luka, S., Sanjuan, J., Banfalvi, Z., Nieuwkoop, A. J., Chun, J. Y., Forsberg, L. S. \& Carlson, R. (1994). nodZ, a unique hostspecific nodulation gene, is involved in the fucosylation of the lipooligosaccharide nodulation signal of Bradyrhizobium japonicum. J Bacteriol 176, 620-633.

Steenkamp, E. T., Stępkowski, T., Przymusiak, A., Botha, W. J. \& Law, I. J. (2008). Cowpea and peanut in southern Africa are nodulated by diverse Bradyrhizobium strains harboring nodulation genes that belong to the large pantropical clade common in Africa. Mol Phylogenet Evol 48, 1131-1144.
Stępkowski, T., Świderska, A., Miedzinska, K., Czaplińska, M., Świderski, M., Biesiadka, J. \& Legocki, A. B. (2003). Low sequence similarity and gene content of symbiotic clusters of Bradyrhizobium sp. WM9 (Lupinus) indicate early divergence of "lupin" lineage in the genus Bradyrhizobium. Antonie van Leeuwenhoek 84, 115-124.

Stępkowski, T., Moulin, L., Krzyzańska, A., McInnes, A., Law, I. J. \& Howieson, J. (2005). European origin of Bradyrhizobium populations infecting lupins and serradella in soils of Western Australia and South Africa. Appl Environ Microbiol 71, 7041-7052.

Stępkowski, T., Hughes, C. E., Law, I. J., Markiewicz, L., Gurda, D., Chlebicka, A. \& Moulin, L. (2007). Diversification of lupine Bradyrhizobium strains: evidence from nodulation gene trees. Appl Environ Microbiol 73, 3254-3264.

Sterner, J. P. \& Parker, M. A. (1999). Diversity and relationships of bradyrhizobia from Amphicarpaea bracteata based on partial nod and ribosomal sequences. Syst Appl Microbiol 22, 387-392.

Turner, S. L. \& Young, J. P. (2000). The glutamine synthetases of rhizobia: phylogenetics and evolutionary implications. Mol Biol Evol 17, 309-319.

Vinuesa, P., Rojas-Jiménez, K., Contreras-Moreira, B., Mahna, S. K., Prasad, B. N., Moe, H., Selvaraju, S. B., Thierfelder, H. \& Werner, D. (2008). Multilocus sequence analysis for assessment of the biogeography and evolutionary genetics of four Bradyrhizobium species that nodulate soybean on the Asiatic continent. Appl Environ Microbiol 74, 6987-6996.

You, Z., Marutani, M. \& Borthakur, D. (2002). Diversity among Bradyrhizobium isolates nodulating yardlong bean and sunnhemp in Guam. J Appl Microbiol 93, 577-584.

Young, J. P. W. (1992). Phylogenetic classification of nitrogen-fixing organisms. In Biological Nitrogen Fixation, pp. 43-79. Edited by G. Stacey, H. R. Burris \& H. J. Evans. New York: Chapman and Hall.

Young, J. P. W. \& Haukka, K. E. (1996). Diversity and phylogeny of rhizobia. New Phytol 133, 87-94.

Zehr, J. P., Wyman, M., Miller, V., Duguay, L. \& Capone, D. G. (1993). Modification of the Fe protein of nitrogenase in natural populations of Trichodesmium thiebautii. Appl Environ Microbiol 59, 669-676.

Zhao, C. T., Wang, E. T., Chen, W. F. \& Chen, W. X. (2008). Diverse genomic species and evidences of symbiotic gene lateral transfer detected among the rhizobia associated with Astragalus species grown in the temperate regions of China. FEMS Microbiol Lett 286, 263-273. 